\title{
Role of radiation therapy in treating intracranial meningiomas*
}

\author{
Leland Rogers, M.D., ${ }^{1}$ AND Minesh Mehta, M.D. ${ }^{2}$ \\ ${ }^{\prime}$ GammaWest Radiation Therapy, Salt Lake City, Utah; and '2Department of Human Oncology, \\ University of Wisconsin School of Medicine and Public Health, Madison, Wisconsin
}

\begin{abstract}
$\checkmark$ Surgery is the mainstay for many patients with meningiomas, and it remains the standard. In large single-institution series, gross-total resection has been reported to achieve 5-, 10-, and 15-year recurrence-free survival rates of approximately 90, 80, and 70\%, respectively. There are a growing number of series of patients with prolonged follow-up in which authors have evaluated fractionated external-beam radiation therapy (EBRT) either as an adjuvant to surgery for subtotally resected, recurrent, or higher-grade meningiomas, or as an alternative to surgery. The primary focus of this review is EBRT, but to lend perspective, a comparative analysis of surgery and radiosurgery is also provided.
\end{abstract} (DOI: 10.3171/FOC-07/10/E4)

KEY WORDS • brain neoplasm • meningioma • radiation therapy • radiosurgery

$\mathrm{C}$ USHING coined the term "meningioma"26 to describe tumors that principally originate from the meningeal coverings of the brain and spinal cord. Considerable progress has been made characterizing histological grades, defining aggressive variants, and modernizing approaches to treatment, but many crucial questions remain. In part, this is because meningiomas tend to progress slowly and thus require long-term vigilance, which reveals that considerable morbidity, and even death can be caused by this neoplasm. ${ }^{22,43}$

\section{Epidemiology}

Meningiomas are now the most frequently reported primary intracranial neoplasm, ${ }^{22}$ constituting approximately $30 \%$ of primary central nervous system tumors. ${ }^{16,17,22,67,68}$ Many are identified solely on the basis of imaging findings; in recent studies, 35 to $62 \%$ were diagnosed on the basis of imaging alone. ${ }^{31,35}$ Furthermore, meningiomas have been identified in $2.3 \%$ of all autopsy reports. ${ }^{91}$ Therefore, it is likely that more intensive use of imaging will increase the detection of meningimas.

Abbreviations used in this paper: EBRT = external-beam radiation therapy; GTR = gross-total resection; MR = magnetic resonance; NF2 = neurofibromatosis Type 2; ONSM = optic nerve sheath meningioma; PFS = progression-free survival; SRS = stereotactic radiosurgery; STR $=$ subtotal resection; $\mathrm{WHO}=$ World Health Organization..
The risk of a patient developing a meningioma increases with age. ${ }^{1,22,85,133}$ Meningiomas have rarely been reported during fetal development and infancy., ${ }^{74,97,100,157}$ Except in the setting of NF2,100 however, they are infrequent in the pediatric population. ${ }^{80,100}$ More aggressive clinical and histological features have been noted in children and young adults. ${ }^{99}$ In terms of the absolute numbers of meningiomas, the peak incidence occurs during the sixth and seventh decades of life. ${ }^{102}$ However, the age-specific rate of development of meningiomas continues to rise thereafter. Figure 1 , created based on data from a large epidemiological study published in 2005, highlights that the age-specific incidence continues to rise even for individuals older than 85 years. ${ }^{22}$

Meningiomas occur more frequently in females, with a female/male ratio of approximately $2: 1 .^{41,74,80,85,133,150}$ Progesterone and estrogen receptors have been identified in greater than 70 and $30 \%$ of meningiomas, respectively. ${ }^{102,149}$ Increased estrogenicity is associated with an increase in tumor-related symptoms during pregnancy or the luteal phase of menses. ${ }^{30,149}$ An increased risk of breast cancer has been described in patients with meningioma, as has an

\footnotetext{
*This article is an adaptation of the chapter "Intracranial Meningiomas: Perspective-Fractionated Radiation Therapy" by Leland Rogers, Dennis Shrieve, and Arie Perie, which will appear in the book Principles and Practice of Stereotactic Radiosurgery, edited by Lawrence Chin and William Regine, soon to be published by Springer.
} 


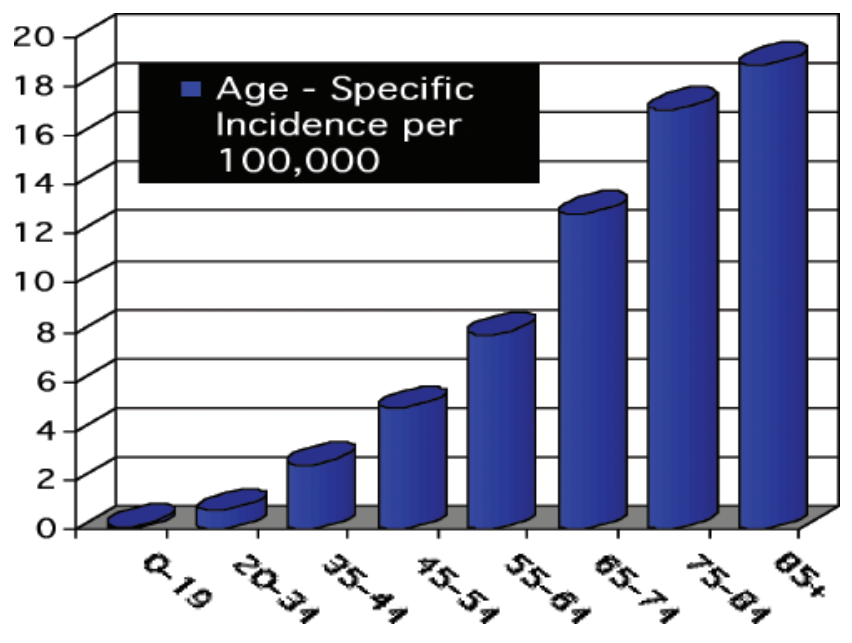

FIG. 1. Bar graph demonstrating the age-specific incidence of meningioma, based on data from the Central Brain Tumor Registry of the United States. The graph was derived using data from the article by Claus et al.

increased relative risk of meningiomas with breast cancer. ${ }^{149}$ However, androgen receptors have been identified in nearly $40 \%$ of meningiomas, ${ }^{102}$ and therapies designed to exploit hormone receptor overexpression have, to date, met with disappointing results. ${ }^{98,112}$

\section{Origin of Meningiomas}

The origin of the majority of meningiomas is unknown. ${ }^{22}$ Associations have been made with hormones, growth factors, NF2, ionizing radiation, and trauma. 5,10,30,36,39,48,51,80,99, 100,102,118,119,139 Nearly all NF2-associated meningiomas have mutations of the NF2 gene on 22q12. ${ }^{115}$ Most families identified as susceptible to meningiomas have alterations of the NF2 locus on chromosome 22..$^{75,115}$ Monosomy of chromosome 22 is the most common cytogenetic alteration in meningiomas.

\section{Histopathology}

\section{Cell of Origin}

Meningiomas are believed to arise from arachnoid cap cells (the epithelioid cells on the outer surface of arachnoid villi), or meningothelial progenitor cells. ${ }^{23,121}$ Meningiomas are cytologically similar to cells within arachnoid caps; arachnoid villi are identified in greater numbers at sites where meningiomas frequently arise; and cap cell clusters appear to increase with age, paralleling the age-related occurrence of meningiomas. $^{97}$

\section{Tumor Grade}

The WHO published its grading criteria in $2000 .{ }^{76}$ An update is expected this year (2007). The 2000 and 2007 criteria are expected to be similar; brain invasive meningiomas are now regarded as Grade II, even in the absence of atypia or anaplasia. ${ }^{102}$ As depicted in Fig. 2, using these criteria, stronger associations between grade and outcome have been demonstrated in large series. . $6,65,103,104^{-10}$

Benign meningiomas (WHO Grade I) constitute approx-

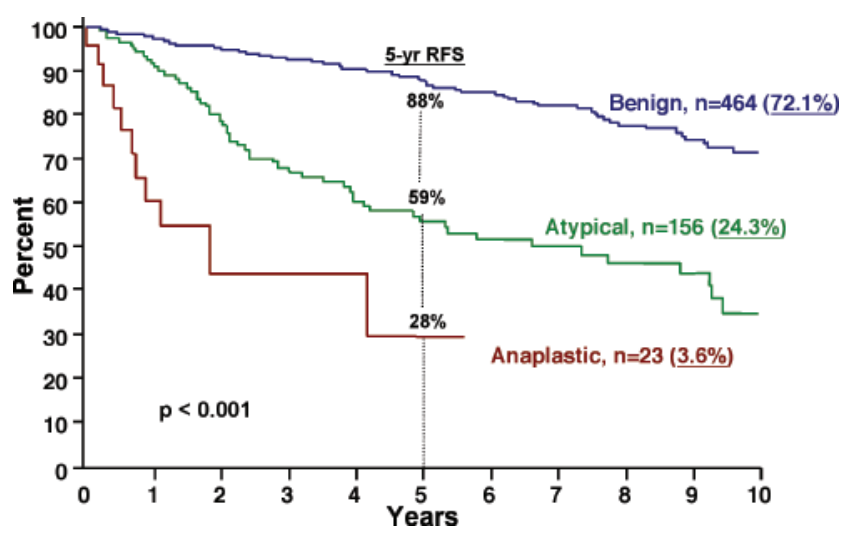

FIG. 2. Kaplan-Meier estimated recurrence-free survival (RFS) by WHO tumor grade from a compiled series of 643 patients from studies by Perry et al., 1997 and 1999. The number of patients with each grade is given, as is the percentage of patients with each grade. The grading criteria used in this study have been incorporated into the current WHO grading scheme. Courtesy of Christine Lohse, Biostatistics Division, Mayo Clinic, and reprinted with permission from Springer.

imately 70 to $85 \%$ of intracranial meningiomas. With appropriate treatment, more than $80 \%$ of WHO Grade I meningiomas remain progression-free at 10 or more years. $^{24,94,103,104}$ Atypical meningiomas (WHO Grade II) likely account for 15 to $25 \%$ of intracranial meningiomas. ${ }^{103,104,153}$ Authors of single-institution series have tended to include a smaller percentage of patients with Grade II tumors, ranging from 4.7 to $9.6 \% .^{54,82}$ It is important to recognize Grade II meningiomas, given that they carry a seven- to eightfold increased recurrence risk at 3 to 5 years. ${ }^{98}$ Only approximately 40 to $60 \%$ of patients with Grade II meningiomas remain disease-free at 10 years. ${ }^{24,48,54,103,104}$ One to four percent of intracranial menin-

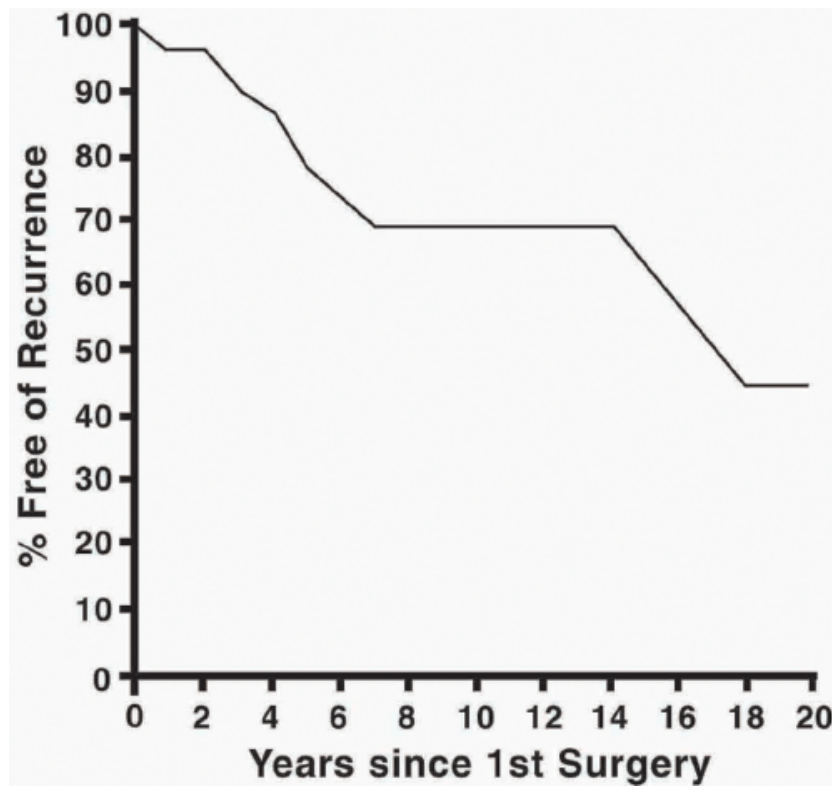

FIG. 3. Cumulative proportion of patients free of recurrence against the number of years since surgery. Reprinted with permission from Adegbite et al., J Neurosurg 58:51-56, 1983. 
TABLE 1

Extent of resection according to Simpson grading*

\begin{tabular}{|c|c|c|}
\hline $\begin{array}{c}\text { Resection } \\
\text { Grade }\end{array}$ & Definition & $\begin{array}{c}\text { Recurrence } \\
(\%)\end{array}$ \\
\hline 1 & GTR of tumor, dural attachments, \& abnormal bone & 9 \\
\hline 2 & GTR of tumor, coagulation of dural attachments & 19 \\
\hline 3 & $\begin{array}{l}\text { GTR of tumor w/o resection or coagulation of } \\
\text { dural attachments or extradural extensions } \\
\text { (invaded or hyperostotic bone) }\end{array}$ & 29 \\
\hline 4 & partial resection of tumor & 44 \\
\hline 5 & simple decompression (biopsy) & - \\
\hline
\end{tabular}

giomas are anaplastic (WHO Grade III). ${ }^{54,103,104,153}$ They have a median recurrence-free survival of fewer than 2 years. ${ }^{103,104}$ We plan no specific review of Grade III meningiomas.

\section{Treatment and Outcome}

Authors of many studies have highlighted excellent local control after resection, radiosurgery, and fractionated EBRT at approximately 5 years, but this cannot be considered definitive. Adegbite and coworkers ${ }^{1}$ documented that even with thorough resection, the likelihood of recurrence is high with a sufficient observation interval of 15-20 years (Fig. 3). A few other series, also with long-term follow-up, have shown that gross totally resected meningiomas recur $20-30 \%$ of the time at 10 to 15 years. ${ }^{24,85,133}$

\section{Surgical Resection}

The completeness of surgical removal is an important prognostic feature..$^{24,29,108,133}$ Resection of the meningioma, its involved dura, and any involved soft tissue and bone is an accepted procedure, ${ }^{30}$ and achieves high rates of local control. The extent of resection was classically defined by Simpson, ${ }^{128}$ who linked it to recurrence risk, summarized in Table 1. Kinjo and colleagues ${ }^{61}$ defined a more extensive resection as "grade zero," entailing gross-total resection of the primary, any hyperostotic bone, and all involved dura with a $2 \mathrm{~cm}$ dural margin. They observed no local recur-

TABLE 2

Sites of meningioma in 581 patients*

\begin{tabular}{lc}
\hline \hline \multicolumn{1}{c}{ Site } & \% of Patients \\
\hline parasagittal falx & 18.6 \\
convexity & 16.8 \\
multiple sites $\dagger$ & 16.3 \\
sphenoid wing & 15.3 \\
posterior fossa & 13.6 \\
parasellar area & 10.5 \\
anterior visual pathway & 2.5 \\
clivus & 2.4 \\
foramen magnum & 2.4 \\
intraventricular area & 1.0 \\
\hline
\end{tabular}

* Due to the requirements of rounding, adding the percentages amounts to $99.4 \%$

$\dagger$ The item "multiple sites" refers principally to meningiomas which occupy more than one area. Only 3\% of patients had multiple lesions. Reprinted with permission from Stafford et al., Mayo Clinic Proceedings 73:936-942, 1998.
TABLE 3

Relative frequency of complete excision in 225 patients

\begin{tabular}{lcc}
\hline \hline $\begin{array}{c}\text { Meningioma } \\
\text { Location }\end{array}$ & $\begin{array}{c}\text { No. of } \\
\text { Patients }\end{array}$ & $\begin{array}{c}\text { \% Complete } \\
\text { Excision }\end{array}$ \\
\hline convexity & 47 & 96 \\
orbit & 5 & 80 \\
spine & 18 & 78 \\
olfactory groove & 22 & 77 \\
parasagittal area/falx & 38 & 76 \\
parasellar region & 28 & 57 \\
posterior fossa & 31 & 32 \\
sphenoid ridge & 36 & 28 \\
total & 225 & 64 \\
\end{tabular}

rences, with more than half of 37 patients followed over 5 years. ${ }^{61}$

Table 2 reviews the distribution of intracranial meningiomas. The likelihood of gross-total resection varies considerably by primary sites. ${ }^{29,41,85,108}$ Table 3 reviews the likelihood of complete excision. Overall, at least one third of meningiomas reported in surgical series are not fully resected. ${ }^{85,108}$

Gross-Total Resection Alone. Gross-total resection for benign meningiomas is considered definitive. ${ }^{24,85,108,133}$ Three large series with extended follow-up are listed in Table 4. Remarkably similar local recurrence rates were reported in all: 7 to $12 \%, 20$ to $25 \%$, and 24 to $32 \%$ at 5, 10, and 15 years, respectively. Typically, GTR connotes Simpson Grades 1 and 2, ${ }^{108}$ and sometimes Grade 3 resection. $.^{24} \mathrm{Au}-$ thors of a study conducted at the University of Florida found no significant difference in local control or causespecific survival between Simpson Grade 1 to 3 resections. ${ }^{24}$

Subtotal Resection Alone. Subtotal resection alone remains common in practice, and Table 5 summarizes outcomes following STR alone, from four series of patients with 10 to 20 years of follow-up; the 5-, 10-, and longer than 15 -year progression rates following subtotal resection were 37 to $47 \%, 55$ to $63 \%$, and greater than $70 \%$, respectively. ${ }^{24,85,133,151}$

\section{Radiation Therapy}

Radiation therapy improves local control. Factors considered in the decision to use radiotherapy include the extent of resection, ${ }^{24,85,128,133}$ grade, ${ }^{103,104}$ and histological subtype. ${ }^{76}$ Secondarily, one might also consider imaging findings such as edema and calcifications, ${ }^{49,80,89}$ age, ${ }^{55,99}$ and perhaps menopausal status ${ }^{55}$ although these remain less well defined.

\section{TABLE 4}

Three large single-institution series with 10 to 15 years' follow-up, documenting rates of recurrence following GTR alone

\begin{tabular}{lcccc}
\hline \hline \multirow{2}{*}{ Authors \& Year } & No. of Patients & $5-\mathrm{yr}$ & $10-\mathrm{yr}$ & $15-\mathrm{yr}$ \\
\cline { 3 - 5 } & 145 & 7 & 20 & 32 \\
Mirimanoff et al., 1985 & 145 & 7 & 20 & 24 \\
Condra et al., 1997 & 175 & 12 & 25 & - \\
Stafford et al., 1998 & 465 & 12 & \\
\hline
\end{tabular}


TABLE 5

Four single-institution series with 10- to 20-year follow-up, assessing rates of recurrence following STR alone

\begin{tabular}{lccccc}
\hline \hline & & \multicolumn{4}{c}{ Local Progression Rate (\%) } \\
\cline { 3 - 6 } Authors \& Year & No. of Patients & $5-\mathrm{yr}$ & $10-\mathrm{yr}$ & $15-\mathrm{yr}$ & $20-\mathrm{yr}$ \\
\hline Wara et al., 1975 & 58 & 47 & 62 & - & 74 \\
Mirimanoff et al., 1985 & 80 & 37 & 55 & 91 & - \\
Condra et al., 1997 & 55 & 47 & 60 & 70 & - \\
Stafford et al., 1998 & 116 & 39 & 61 & - & - \\
\hline
\end{tabular}

Data pertaining to a total of 42 studies with 4585 patients treated with radiotherapy or radiosurgery are summarized in Tables 6 and 7. These data substantiate that irradiation is beneficial as an adjunct to surgery following subtotal resection, as treatment for recurrent meningiomas, or as primary therapy. For comparative purposes, a brief consideration of radiosurgery for meningiomas follows.

\section{Stereotactic Radiosurgery}

Local control rates following SRS are 75 to $100 \%$ at 5 to 10 years. ${ }^{45,62,64,71,91,108,117,123,134,147}$ Outcomes from several radiosurgery series are summarized in Table 6. Stereotactic radiosurgery is generally considered most appropriate for meningiomas less than 3 to $4 \mathrm{~cm}$ in diameter, with distinct margins, and with sufficient distance from critical healthy tissues to allow for appropriate normal tissue dose restrictions as well as adequate target dose. DiBiase and coauthors ${ }^{31}$ reported 5-year disease-free survival rates of $91.9 \%$ for patients with meningiomas $10 \mathrm{~cm}^{3}$ or smaller (equivalent diameter $2.7 \mathrm{~cm}$ ) versus $68 \%$ for larger tumors. Au- thors of many series have used margin doses in the 10- to 18-Gy range. Ganz and associates ${ }^{37}$ noted that a minimum peripheral tumor dose of $10 \mathrm{~Gy}$ or less was associated with a higher risk of failure, whereas at least 12 Gy resulted in improved local control. Morita and colleagues ${ }^{86}$ subsequently recommended tumor margin doses of at least 15 to 16 Gy. Stafford and coauthors ${ }^{134}$ reported no improvement in 5-year local control with doses of at least $16 \mathrm{~Gy}$. Kondziolka and associates ${ }^{62}$ reported no improvement with marginal doses of at least $15 \mathrm{~Gy}$. Margin doses ranging from 12 to 16 Gy are now widely used. $35,64,70,93,116,132$

Early reports of SRS were associated with a high complication rate. For example, in 41 patients with a median follow-up of 3.5 years, Kondziolka and colleagues ${ }^{62}$ noted worse outcomes in cases of larger tumors, prior surgery, or with pre-SRS neurological deficits. The adverse events most frequently attributed to SRS are cranial nerve deficits and peritumoral edema. Serious, but uncommon side effects include radiation necrosis, ${ }^{33,47,62}$ peritumoral cyst formation, ${ }^{134}$ carotid artery stenosis, ${ }^{135}$ and hypothalamic dysfunction. ${ }^{45}$ With margin doses of 14 to $16 \mathrm{~Gy}$, authors of some studies have identified new or worsened cranial nerve deficits in approximately $8 \%$ of patients. ${ }^{31,64,134,136,140,142} \mathrm{Neu}-$ ropathies are encountered more frequently with the optic, cochlear, and trigeminal nerves. Motor nerves tend to tolerate radiosurgery comparatively well. Roche and colleagues ${ }^{117}$ observed no new oculomotor deficits in 80 patients with cavernous sinus meningiomas with a mean maximum prescription dose of 28 Gy and a median followup of 30.5 months. Conversely, sensory nerves of the anterior visual pathway have been particularly susceptible. Doses of only 10 Gy or less ${ }^{86,136}$ carry a roughly 1 or $2 \%$ rate of optic neuropathy. With higher doses, the rate and severity of complications rise steeply. ${ }^{69,136}$

TABLE 6

Compiled stereotactic radiosurgery with reported 5-year PFS rates*

\begin{tabular}{|c|c|c|c|c|c|}
\hline Authors \& Year & No. of Patients & $\mathrm{FU}(\mathrm{mos}) \dagger$ & No Histology $(\%) \ddagger$ & Dose (Gy) & $\geq 5$-yr PFS \\
\hline Chang et al., 1997 & 55 & 48 & - & 18 & 98 \\
\hline Chang et al., 1998 & 24 & 46 & - & 17.7 & 100 \\
\hline Hakim et al., 1998 & 127 & 31 & 54 & 15 & 89 \\
\hline Kondziolka et al., 1999 & 99 & & 43 & 16 & 93 \\
\hline Liscak et al., 1999 & 53 & 19 & 64 & 12 & 100 \\
\hline Morita et al., 1999 & 88 & 35 & 44 & 16 & 95 \\
\hline Roche et al., 2000 & 80 & 31 & 63 & 14 & 93 \\
\hline \multirow[t]{2}{*}{ Shin et al., 2001} & 15 & 42 & 30 & $10-12$ & 75 (5- \& 10-yr PFS) \\
\hline & 22 & & 30 & $14-18$ & 100 (5- \& 10-yr PFS) \\
\hline Stafford et al., 2001 & 168 & & 41 & 16 & 93 \\
\hline Lee et al., 2002 & 159 & 35 & 52 & 13 & 93 (97 if SRS sole tx) \\
\hline Nicolato et al., 2002 & 111 & 48 & 50 & 15 & 96 \\
\hline Spiegelmann et al., 2002 & 42 & 36 & - & 14 & 97.5 \\
\hline Flickinger et al., 2003 & 219 & 29 & 100 & 14 & 93 (5- \& 10-yr PFS) \\
\hline Iwai et al., 2003 & 42 & 49 & 48 & 11 & 92 \\
\hline Pollock et al., 2003 & 62 & 64 & 46 & 17.7 & 95 (7-yr PFS) \\
\hline Roche et al., 2003 & 32 & 56 & 75 & 13 & 100 \\
\hline Chuang et al., 2004 & 43 & 75 & 48 & 16 & $\begin{array}{l}90(7-y r \text { PFS }) \\
(100 \text { if SRS sole tx })\end{array}$ \\
\hline DiBiase et al., 2004 & 137 & 54 & 62 & 14 & $86.2\left(91.9\right.$ if $\left.<10 \mathrm{~cm}^{3}\right)$ \\
\hline Zachenhofer et al., 2006 & 36 & 103 & 31 & 16.8 & 94 (at 5 \& 8 yrs) \\
\hline
\end{tabular}

* Patients in these reports typically, but not exclusively, had either known or presumed low-grade meningiomas. Abbreviations:

$\mathrm{FU}=$ follow-up; tx = treatment.

$\uparrow$ Stated as the mean or median value.

$\doteqdot$ This column refers to the percentage of patients diagnosed with meningioma on the basis of neuroimaging findings.

$\S$ Actuarial intervals other than 5 years are given in parentheses. 
TABLE 7

Compiled series allowing for comparison in the rates of PFS for patients treated with GTR, STR, or with STR plus EBRT *

\begin{tabular}{|c|c|c|c|c|c|}
\hline \multirow[b]{2}{*}{ Authors \& Year } & \multirow[b]{2}{*}{ No. of Patients } & \multirow[b]{2}{*}{$\mathrm{FU}(\mathrm{mos})$} & \multicolumn{3}{|c|}{ 5-yr PFS (\%) } \\
\hline & & & GTR & STR & STR \& EBRT $\dagger$ \\
\hline Adegbite et al., 1983 & 114 & $10-276$ & 90 & 45 & 82 \\
\hline Mirimanoff et al., 1985 & 225 & $>60(65 \%)$ & 93 & 63 & \\
\hline Barbaro et al., 1987 & 135 & 78 & 96 & 60 & 80 \\
\hline Taylor et al., 1988 & 132 & $>60(60 \%)$ & 96 & 43 & 85 \\
\hline Glaholm et al., 1990 & 117 & 80 & & & 84 \\
\hline Miralbell et al., 1992 & 115 & 57 & & 48 & 88 (8-yr PFS) \\
\hline Goldsmith et al., 1994 & 117 & 40 & & & 89 (98 after 1980) \\
\hline Mahmood et al., 1994 & 254 & 61 & 98 & 54 & \\
\hline Peele et al., 1996 & 86 & 46 & & 52 & 100 \\
\hline Condra et al., 1997 & 246 & 98 & 95 & 53 & 86 \\
\hline Stafford et al., 1998 & 581 & 55 & 88 & 61 & \\
\hline Maguire et al., 1999 & 28 & 41 & & & 92 (4-yr PFS) \\
\hline Nutting et al., 1999 & 82 & 108 & & & 92 \\
\hline Vendrely et al., 1999 & 156 & 40 & & & 89 \\
\hline Wenkel et al., 2000 & 46 & 53 & & & 100 \\
\hline Debus et al., 2001 & 189 & 35 & & & 98 (FSRT) \\
\hline Dufour et al., 2001 & 31 & 73 & & & 93 (10-yr PFS) \\
\hline Pourel et al., 2001 & 26 & 30 & & & 95 \\
\hline Uy et al., 2002 & 40 & 30 & & & 93 \\
\hline Pirzkall et al., 2003 & 20 & 36 & & & 100 \\
\hline Selch et al., 2004 & 45 & 36 & & & 98 (3-yr PFS) \\
\hline Soyuer et al., 2004 & 92 & 92 & 77 & 38 & 91 \\
\hline Milker-Zabel et al., 2007 & 94 & 53 & & & 93.6 (Grade I 96.3) \\
\hline
\end{tabular}

* Patients in these reports typically, but not exclusively, had either known or presumed low grade meningiomas. Abbreviation: FSRT $=$ fractionated stereotactic radiosurgery.

$\dagger$ Actuarial intervals other than 5-years are given in parentheses.

Posttreatment edema has been widely reported subsequent to SRS (Table 8) ${ }^{38,59,62,90,113,147}$ Meningiomas produce vasoactive mediators. ${ }^{56,80,95,111}$ Edema is more commonly encountered with nonbasal primary tumors, which are apt to have a broader pial interface ${ }^{6,49}$ permitting vasogenic substrates greater access to adjacent brain. Basal primaries have more limited pial involvement. ${ }^{6,49,50}$ Edema developed in 25 to $78 \%$ of the patients with nonbasal meningioma, compared with 0 to $22 \%$ of patients with basal primary tumors. With parasagittal meningiomas, for which edema has been frequently reported, ${ }^{62}$ bridging vein and/or sagittal sinus occlusion may also contribute. Other factors potentially associated with an increased risk of edema are the following: margin dose greater than $15 \mathrm{~Gy}$, tumor size (diameter $\geq 3 \mathrm{~cm}$ or volume $\geq 4 \mathrm{~cm}^{3}$ ), and the presence of pretreatment edema.

\section{External-Beam Radiation Therapy}

Meningiomas were historically considered resistant to irradiation, ${ }^{60,85}$ and authors of several older retrospective studies described infrequent radiographic regression. ${ }^{1,60}$, ${ }^{148,155} \mathrm{In}$ addition, there has been apprehension regarding the malignant degeneration of irradiated tumors as well as about the relationship between irradiation and the ultimate development of meningiomas. ${ }^{40,118,119,139}$ Therefore, many patients with inoperable or subtotally resected meningiomas have been observed. ${ }^{3,55,133}$ Malignant degeneration now is widely believed to be related to the natural history of a subgroup of meningiomas, and has never been explicitly linked with radiation therapy. The risk of developing a meningioma after cranial irradiation has been reviewed by Strojan et al., ${ }^{139}$ who reported the actuarial risk after radiation therapy to be $0.53 \%$ at 5 years, and $8.18 \%$ at 25 years.

In the 1970s and early 1980s, several authors reached the conclusion that EBRT improved local control after incomplete resection or recurrence, ${ }^{11,15,18,151}$ despite the fact that meningiomas often remained stable or regressed slowly.

Primary EBRT. Radiation therapy may be used as primary treatment following biopsy, or even on the basis of imaging findings. ${ }^{15,24,77,106,122}$ An early report described $47 \%$ disease-free survival at 15 years in 32 patients who underwent EBRT without resection. This was lower than the $61 \%$ rate following partial resection plus radiotherapy. ${ }^{40}$ In a more recent series, Debus et al. ${ }^{28}$ noted no difference in outcomes between patients who underwent primary EBRT (59 patients) and those who underwent surgery plus EBRT (130 patients). In fact, there were no recurrences in patients treated with radiotherapy alone; the 10-year recurrencefree probabilities were $100 \% .{ }^{28}$ Several other authors have also reported excellent results with primary EBRT. ${ }^{15,24,77,92,106,122}$

Primary EBRT for ONSM. Optic nerve sheath meningiomas arise from the dura encompassing the optic nerve, and account for only 1 to $2 \%$ of meningiomas. ${ }^{13,72,73,81,129}$ Surgery plays a very limited role in the management of ONSMs. Observation results in gradual loss of vision, and surgery is often associated with immediate blindness of the affected eye. Resection of ONSMs while keeping the optic nerve in situ has been tried, but carries a high risk of visu- 
TABLE 8

Six series (with 226 total patients) with new or worsening edema following SRS*

\begin{tabular}{|c|c|c|c|c|c|}
\hline Authors \& Year & $\begin{array}{l}\text { No. of } \\
\text { Patients }\end{array}$ & $\begin{array}{l}\text { FU } \\
(\mathrm{yrs})\end{array}$ & $\begin{array}{l}\text { Dose in Gy } \\
\text { (range) }\end{array}$ & $\begin{array}{l}\text { Edema in \% } \\
\text { (basal vs nonbasal) } \dagger\end{array}$ & Comment \\
\hline Ganz et al., 1996 & 34 & $1-3$ & $15(12-25)$ & $21(7$ vs $71 \%)$ & $\begin{array}{c}86 \% \text { of patients with edema: margin dose } \\
>18 \mathrm{~Gy} ; 12 \text { Gy adequate for LC }\end{array}$ \\
\hline Nakamura et al., 1996 & 48 & 1 & 15 (mean) & $8(0$ vs $25 \%)$ & edema with $15-24 \mathrm{~Gy} ; 25 \%$ resolved \\
\hline Kondziolka et al., 1998 & 203 & 3.5 & $15(9-32)$ & 10 (all parasagittal) & $\begin{array}{l}\text { 3- \& 5-yr actuarial edema } 16 \% \text {; more common } \\
\text { if }>3 \mathrm{~cm} \text { occurred } 1-23 \mathrm{mos} \text { after SRS; } \\
\text { all resolved (median } 15 \mathrm{mos} \text { ) }\end{array}$ \\
\hline Vermeulen et al., 1999 & 95 & 2.3 & $17(8-20)$ & 32 (22 vs $41 \%)$ & $\begin{array}{l}1 \% \text { basal vs } 4 \% \text { non-basal had "deteriorating" } \\
\text { edema w/o tumor growth }\end{array}$ \\
\hline Ramsey et al., 2002 & 23 & 1.4 & $14(9-18)$ & 39 (22 vs $78 \%)$ & $\begin{array}{l}\text { factors for edema: volume }>4 \mathrm{~cm}^{3}(\mathrm{p}=0.005) \\
\text { parasagittal }(\mathrm{p}=0.006) ; \text { pre-SRS edema }(0.06)\end{array}$ \\
\hline Kim et al., 2005 & 26 & 2.7 & $16(12-20)$ & 43 (all nonbasal) & $\begin{array}{l}\text { mean edema more likely if }>4.2 \mathrm{~cm}^{3}(\mathrm{p}=0.02) \\
\text { duration of symptoms } 9 \text { months }\end{array}$ \\
\hline
\end{tabular}

$*$ LC $=$ local control.

$\uparrow$ The methods of assessing edema varied from clinical (Kondziolka) to imaging (Ganz \& Vermeulen) to a combination of both (Nakamura, Ramsey, and Kim).

al complications and local recurrence. ${ }^{8,25,52,58,143}$ Resection commonly impairs the blood supply and results in blindness, even though the nerve is left grossly intact.

External-beam radiation has become integral in the management of ONSMs. ${ }^{92,130,143}$ Turbin et al. ${ }^{143}$ reported on 64 patients with ONSM and found that radiation therapy alone provided more favorable outcomes than observation, surgery alone, or even surgery plus EBRT. They used total doses ranging from 40 to $55 \mathrm{~Gy}$, and had median follow-up periods of 8.3 years. In another study, and after a median follow-up of 51.3 months, Narayan et al..$^{92}$ found no radiographic progression in any of their 14 patients with ONSMs treated with conformal EBRT, and $86 \%$ had either improved or stable visual acuity. This study, along with six additional studies in which highly conformal or fractionated stereotactic therapy was used,in composite analyzing of 75 eyes, has reached similar conclusions. Overall disease control is excellent (95\%); early visual improvement (within 3 months of radiotherapy) is often attained (54.7\%); and complications are relatively uncommon. With these findings, it has been suggested that earlier treatment of symptomatic patients may provide better visual outcome; ${ }^{13}$ however, there is no uniform agreement as to whether patients with both stable ONSMs and stable vision should be approached with observation or early EBRT.

Postoperative EBRT. Many retrospective studies now support a role for postoperative EBRT after STR. These have shown improvement in local control (Table 7), and possibly even survival. ${ }^{24,79}$

Technical Factors and Dose-Volume Considerations. With image-based techniques, treatment can be delivered with more precision and conformality (Fig. 4), and improved results are to be expected. ${ }^{88,122,126}$ Improvements in local control have, in fact, been documented with computed tomography- or MR imaging-based planning. Goldsmith et al. ${ }^{43}$ and Milosevic and colleagues ${ }^{83}$ each substantiated improvements in local control consequent to improved targeting with modern imaging. ${ }^{41}$ Patients whose treatments were planned and delivered in this fashion had a remarkable 10-year PFS rate of $98 \%$ compared with $77 \%$ without. ${ }^{43}$

Recommended doses generally range from 50 to $55 \mathrm{~Gy}$ in fractions of 1.8 to 2.0 Gy. ${ }^{15,24,41,42,66,92,125,144,150}$ Goldsmith et al. ${ }^{43}$ reported that doses greater than 52 Gy resulted in an improved 10-year local control of 93\% compared with $65 \%$ with lower doses, but this finding lost significance on multivariate analysis. Among 67 patients, Winkler et al. ${ }^{154}$ found no clear dose response from 36 to $79.5 \mathrm{~Gy}$.

The recommended planning target volume has ranged from gross tumor volume (that is, the tumor visible on MR imaging) or the gross tumor volume plus a margin, ranging from a few millimeters to up to $4 \mathrm{~cm} \cdot{ }^{8,24,28,40,82,127}$ Marginal failures are uncommon. ${ }^{28,93}$ The targeting of the "dural tail" remains contentious. Figure 5 depicts a dural tail, not included within the defined target. ${ }^{31}$ Pathology studies have revealed the dural tail to be composed entirely or almost entirely of hypervascular dura in most cases, $2,14,57,87,101$ and including it in the radiotherapy field is of questionable value.

Planning target volumes with radiosurgery have tended to include only the contrast-enhancing tumor without a margin. ${ }^{63,64,123,134}$ Nevertheless, as illustrated in Fig. 6, by 1 year the tumor had already modestly responded and the dural tail largely resolved. Nicolato and colleagues ${ }^{93}$ found no advantage to larger radiosurgery margins. With median follow-up of 4 years, they had 100\% tumor growth control with a conformity index (ratio of prescription isodose volume to target volume) of 1.5 or less. Using fractionated radiotherapy with 2-mm margins, Debus et al. ${ }^{28}$ noted no marginal failures in 189 patients with a 3-year median follow-up period.

Another confounding variable in the definition of the planning target volume is hyperostosis..$^{27,105}$ Pieper et al. ${ }^{105}$ correlated imaging to histopathology in 26 patients; tumor invasion of the hyperostotic bone was conclusively present in all but one. In addition, nine of 25 patients without imaging evidence of hyperostosis were found to have histological invasion of bone. It remains unresolved whether resection of bone, or for that matter its inclusion within the radiation therapy target, is necessary for every patient. Recurrence rates for patients who have undergone GTRs not inclusive of hyperostotic bone have traditionally been low, as have recurrences after radiosurgery and EBRT regardless whether neighboring bone was targeted. 


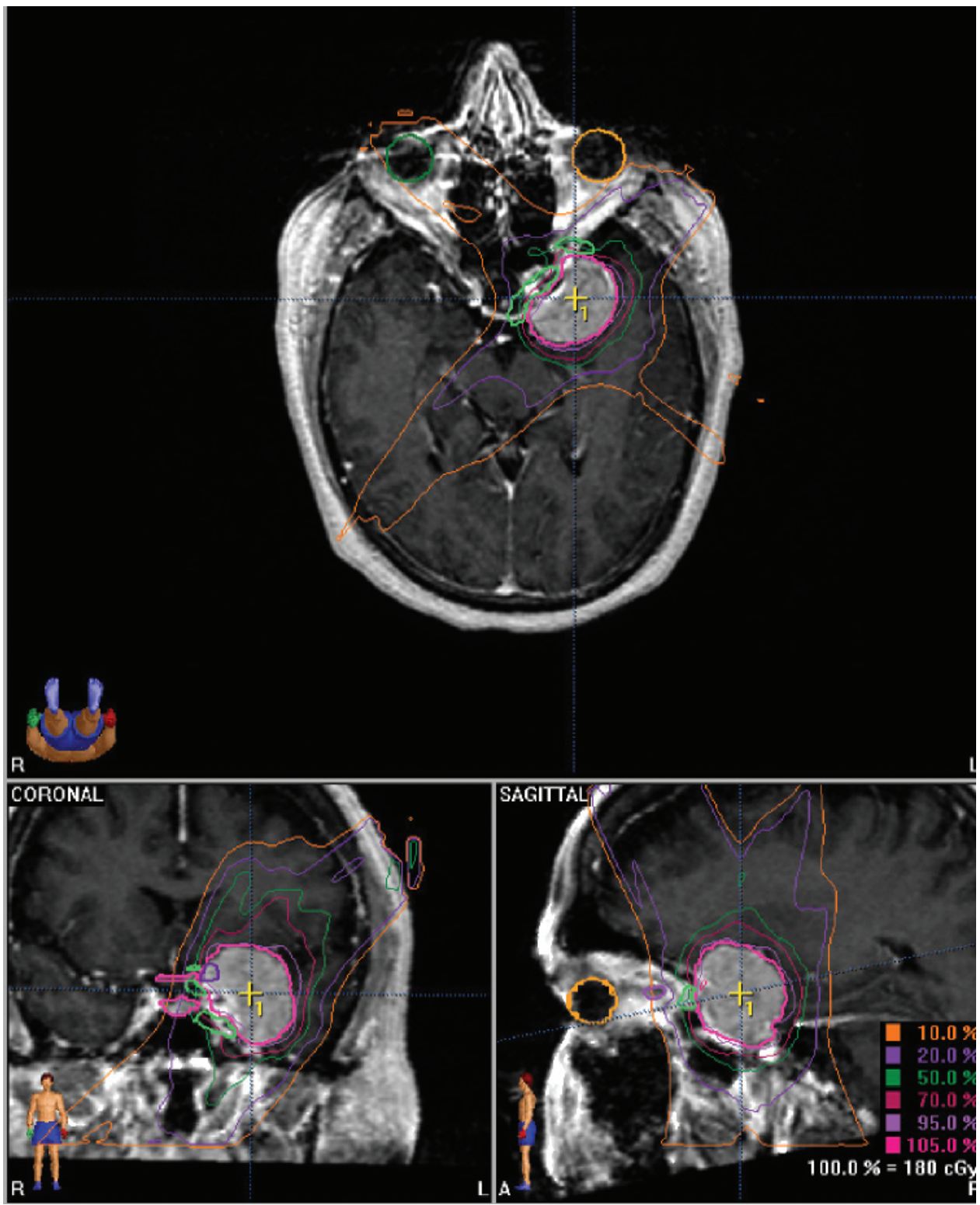

FIG. 4. Magnetic resonance image and isodoses for radiation therapy of a paracavernous meningioma, treated to 54 Gy in 30 fractions. The dose was prescribed at the isocenter. The percentage values for each of the pictured isodoses are given in the legend at the lower right-hand corner of the image. Courtesy of Dennis Shrieve, M.D., Chair of Radiation Oncology, Huntsman Cancer Institute, University of Utah.

Toxicity of EBRT. The side effects of EBRT, especially with current methods of treatment planning and delivery, are relatively uncommon, but by no means are they negligible. In the largest recent series of fractionated irradiation in the literature, Debus et al. ${ }^{28}$ reported on 189 patients treated with a highly conformal stereotactic approach, using median daily fractions of 1.8 Gy to a mean dose of $56.8 \mathrm{~Gy}$. With a median follow-up of nearly 3 years, they identified clinically significant (Grade 3 ) toxicity in four patients $(2.2 \%)$, three $(1.7 \%)$ in the absence of a preexisting deficit. These were reduced vision, a new visual-field deficit, and trigeminal neuropathy. This is, however, a substantial improvement over the $38 \%$ reported by Al-Mefty et al. ${ }^{4}$ with older methods of radiation delivery.
Goldsmith et al. ${ }^{43}$ recognized complications in five (3.6\%) of 140 patients, which they believed may have been attributable to EBRT. These were retinopathy in two, optic neuropathy in one, and cerebral necrosis in two patients. ${ }^{43}$ They also constructed a model to predict optic nerve tolerance, and recommended a maximum dose of 890 optic ret (for example, $54 \mathrm{~Gy}$ in 30 fractions). ${ }^{42}$ Optic complications are quite rare with doses lower than $54 \mathrm{~Gy}$, particularly with fractional doses of $2.0 \mathrm{~Gy}$ or less..$^{40,84,106} \mathrm{Uy}$ et al. ${ }^{145}$ noted no optic pathway toxicity with a median dose of 50.4 Gy and fractions of 1.7 to 2 Gy. The beneficial impact of lower doses per fraction on optic tolerance has been recently confirmed by Shrieve and colleagues, ${ }^{125}$ who concurred that 54 Gy (in 30 fractions) was both safe and effective. 


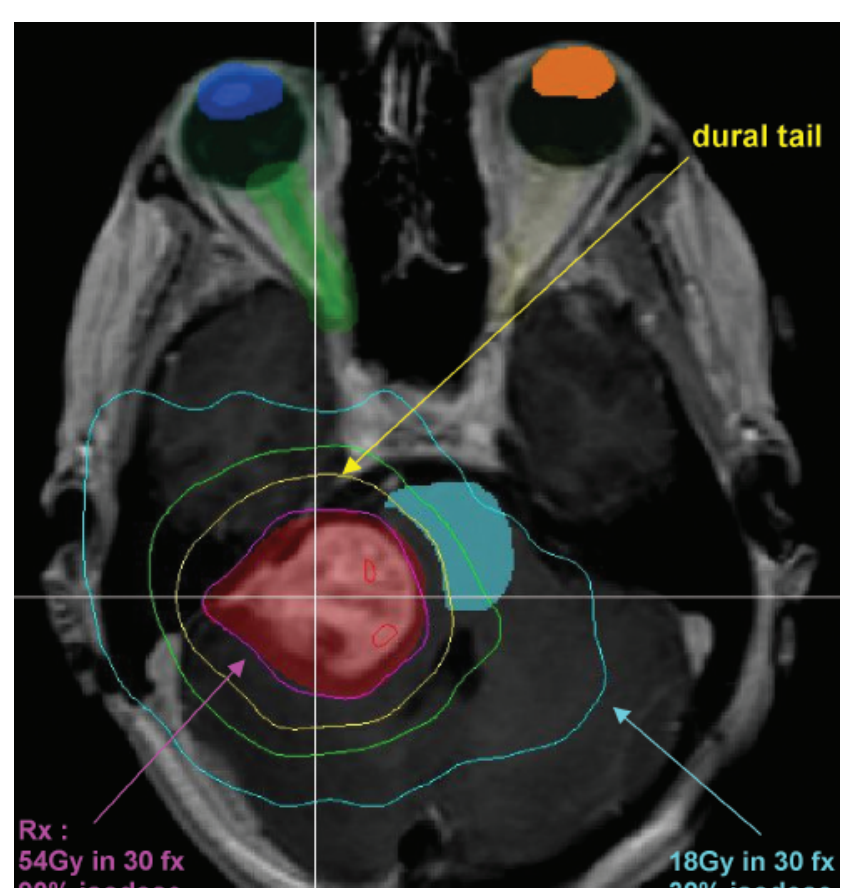

FIG. 5. Magnetic resonance image and isodoses for intensity modulated radiation therapy of a cerebellopontine angle meningioma, treated to $54 \mathrm{~Gy}$ in 30 fractions (fx) prescribed to the $90 \%$ isodose. In this case, the dural tail was not specifically targeted, although it was largely encompassed by the $70 \%$ isodose volume. The yellow line is the $70 \%$ isodose, green $50 \%$, and sky-blue $30 \%$.

Nonocular cranial nerve deficits may occur ${ }^{28}$ but are uncommon. Selch and colleagues ${ }^{122}$ found no treatment-related cranial neuropathy in 45 patients with cavernous sinus meningiomas that were treated with fractions of 1.7 to 1.8 Gy to a median dose of $50.4 \mathrm{~Gy}$. Urie and coauthors ${ }^{144}$ also remarked that doses in this range rarely cause cranial neuropathy.

Brain or brainstem necrosis is also uncommon but has been observed by Goldsmith et al. ${ }^{42}$ and others. ${ }^{4,84} \mathrm{Al}$-Mefty et al. ${ }^{4}$ reviewed post-EBRT toxicity in 58 adult patients with a variety of skull base, parasellar, or pineal region tumors. Seventeen (29\%) developed late brain parenchymal changes, with latencies of 4 months to 23 years. These included encephalomalacia, cerebral atrophy, gliosis, and/ or necrosis, generalized or involving the temporal lobes in $14(82 \%)$ of the 17 cases. ${ }^{4}$ Such occurrences are almost certainly related to antiquated treatment techniques, for example, low-energy opposed lateral fields. Integral doses to the temporal lobes and to large volumes of untargeted brain are much lower with current multifield conformal and intensity modulation.

Pituitary dysfunction, ${ }^{4,84,94,106}$ cerebrovascular events, ${ }^{40}$, ${ }^{94,122}$ second malignancy, ${ }^{4,94}$ orbital fibrosis, ${ }^{77}$ and other sporadic toxicities have been noted. In an older series in which an array of techniques and doses was used, Glaholm et al. ${ }^{40}$ found that all complications occurred with the convention of treating only a portion of the fields daily, and with fractional doses greater than 1.8 Gy (to final doses of 50-55 Gy).

Edema is uncommon following EBRT. Table 7 summarizes data from 23 EBRT studies with a total of 2971 patients. Only six patients $(0.2 \%)$ reportedly developed edema, and two of these six were asymptomatic. Selch and colleagues ${ }^{84}$ who specifically evaluated edema, noted none in 45 patients with 3 years of median follow-up.

Authors of some retrospective studies, typically with less conformal techniques, have identified personality changes, ${ }^{145}$ and memory loss ${ }^{24,77,84.94}$ as complications of EBRT. Cognitive outcome was prospectively evaluated by Steinvorth et al., ${ }^{137}$ with the aid of a comprehensive battery administered before, after the first fraction, at completion, and 12 months subsequent to EBRT. They observed no significant cognitive deterioration. ${ }^{137}$

\section{Treatment of Atypical Meningiomas}

Atypical (WHO Grade II) meningiomas comprise roughly $20 \%$ of all meningiomas (Fig. 2). Most investigators have recommended irradiation, irrespective of resection extent. ${ }^{24,48,154}$ However, in one study, in which eight of 22 patients with atypical meningiomas received postoperative EBRT, local control was $87 \%$ at 5 and 10 years following GTR, and EBRT had no significant impact on local control or overall survival. ${ }^{44}$ That series highlighted some of the difficulties in deciphering the literature respective to atypical tumors. The sample size is small, the percentage of patients with Grade II tumors (6.7\%) is too low to be representative of current WHO grading, and the doses used (50-54 Gy) may be too low for Grade II tumors..$^{48} \mathrm{Hug}$ and associates ${ }^{48}$ found that the local control of atypical meningiomas was significantly enhanced by cumulative doses of at least 60 cobalt Gy equivalents. ${ }^{48}$ Perry and colleagues ${ }^{104}$ reported 108 atypical meningiomas treated with modern surgical techniques, grading, and postoperative imaging and found a 5-year recurrence rate of $40 \%$ even after GTR. In another study, recurrences of atypical meningiomas after either subtotal or "radical subtotal resection" were 39 and $61 \%$ at 5 and 10 years, respectively. ${ }^{133}$

Radiosurgery has been used in the treatment of atypical meningiomas. Stafford and colleagues ${ }^{134}$ described 5-year actuarial local control of $93 \%$ for Grade I meningiomas, compared with $68 \%$ for Grade II meningiomas. This is very similar to the $64 \%$ (seven of 11 patients) reported by Condra et al. ${ }^{24}$ with lower EBRT doses, but inferior to the 5 -year local control of $90 \%$ with at least 60 cobalt Gy equivalents observed by Hug and coauthors. ${ }^{48}$ There is relative consensus for irradiation following subtotal resection; however, it is difficult at present to predict which patients with Grade II tumors that were gross-totally resected will benefit from adjuvant therapy.

\section{Treatment of Recurrent Meningiomas}

Recurrent meningiomas exhibit a several-fold increased rate of progression over newly diagnosed tumors. ${ }^{24,84,85,141}$ Miralbell and coauthors ${ }^{84}$ found a 78\% 8-year PFS in patients treated with surgery and EBRT for recurrent tumors, versus $11 \%$ with surgery alone ${ }^{84}$ Similarly, Taylor et al. ${ }^{141}$ found the respective 5-year PFS rates to be $88 \%$ compared with $30 \%{ }^{141}$ They noted that the 5-year overall survival was $90 \%$ with surgery plus EBRT compared with $45 \%$ after surgery alone. These data support aggressive treatment for recurrent meningiomas. 

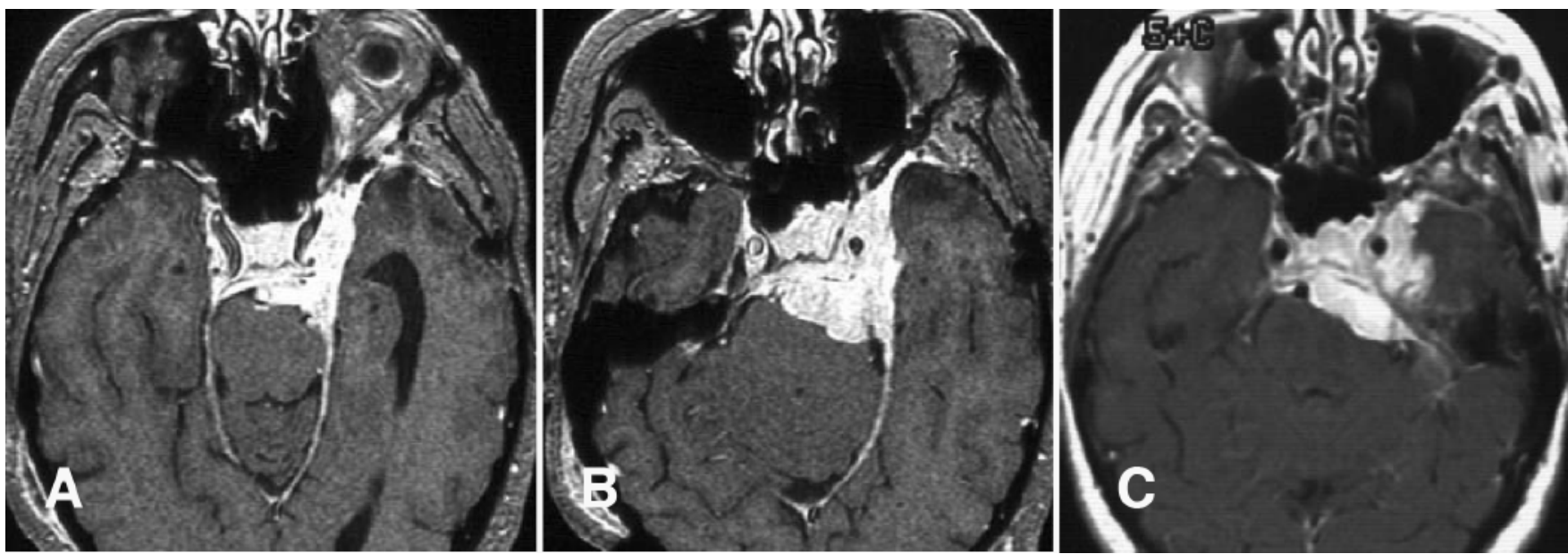

FIG. 6. Magnetic resonance images before and after radiosurgery of a large petroclival and cavernous sinus meningioma treated with single fraction radiosurgery, $14 \mathrm{~Gy}$ to the $50 \%$ isodose. The dural tail was not targeted. A: The long enhancing tails of dura bilaterally around the tentorium are seen. B: The largest pretreatment dimensions of the meningioma are shown. C: Follow-up image obtained 1 year after radiosurgery, demonstrating modest tumor shrinkage and resolution of the majority of the untreated dural tail.

\section{Comparative Outcome: EBRT and SRS}

Tables 6 and 7 display data from numerous studies suggesting relative equivalence of EBRT and SRS with regard to PFS, with the caveat that patient selection differs significantly between these two approaches. Table 9 encapsulates these data further and reveals that 5- to 10-year PFS rates have ranged from 80 to $100 \%$ with EBRT and from 75 to $100 \%$ with SRS. For example, Sibtain and Plowman ${ }^{127}$ published a study comparing EBRT and SRS for cavernous sinus meningiomas. They retrospectively evaluated 13 patients with tumors smaller than $3 \mathrm{~cm}$ in diameter, most of whom received radiosurgery, and 15 patients with tumors larger than $3 \mathrm{~cm}$, most of whom had EBRT. Tumors in all patients were locally controlled (follow-up 12-83 months).

\section{Conclusions}

As a consequence of a frequently observed pattern of slow growth as well as a lack of large cooperative group or randomized trials, standardized recommendations are difficult to formulate. With these limitations, we make the following suggestions.

Small, asymptomatic, stable, or slowly progressive meningiomas can be carefully observed with clinical evaluations and serial imaging. For other patients, GTR remains the benchmark against which other therapeutic strategies should be measured. However, complete removal within the constraints of acceptable morbidity is often not possible. Indeed, meningiomas of the cavernous sinus or petroclival region often involve critical neural or vascular structures, and are generally unresectable. ${ }^{138}$

Following subtotal resection, radiation therapy improves local control, and in some series, survival. ${ }^{24}$ However, there are no randomized data to support this observation, and it is still debatable whether these patients should be carefully observed or treated preemptively. This decision is complex, given that some patients will do well for many years after subtotal resection alone.

There is growing experience with radiotherapy (EBRT or SRS) as a primary treatment modality, either after a limited biopsy or based purely on imaging findings. Fractionated EBRT and radiosurgery result in comparable local control rates, and either can be recommended for many patients, but not for all. External-beam radiation therapy is suitable for a broader range of patients, whereas excellent outcome with SRS is realized among a more selected cohort. Radiosurgery is most judiciously applied to smaller meningiomas located at an adequate distance from the optic apparatus, and perhaps those associated with a low risk for developing edema. Fractionated EBRT does not have these limitations. With currently accepted techniques and dose and fractionation guidelines, EBRT appears to carry only a small risk of side effects such as optic neuropathy or edema.

\section{References}

1. Adegbite AB, Kahn MI, Paine KWE, Tan LK: The recurrence of intracranial meningiomas after surgical treatment. J Neurosurg 58:51-56, 1983

2. Ahmadi J, Hinton DR, Segall HD, Couldwell WT: Surgical implications of magnetic resonance-enhanced dura. Neurosurgery 35: 370-377, 1994

3. Akeyson EW, McCutcheon IE: Management of benign and

TABLE 9

Compiled series allowing comparison of fractionated EBRT with SRS, with 5- to 10-year PFS as the end point*

\begin{tabular}{lccc}
\hline \hline Treatment Type $\dagger$ & $\begin{array}{c}\text { No. of } \\
\text { Patients }\end{array}$ & $\begin{array}{c}\text { FU range in mos } \\
\text { (mean or median) }\end{array}$ & $\begin{array}{c}\text { 5- to } \\
\text { 10-yr PFS }(\%)\end{array}$ \\
\hline SRS combined & 1614 & $19-75$ & $75-100$ \\
EBRT combined & 2971 & $30-108$ & $80-100$ \\
SRS recent & 883 & $29-103$ & $90-100$ \\
EBRT recent & 291 & $30-92$ & $91-100$ \\
\hline
\end{tabular}

* Patients in the above reports typically, but not exclusively, had either known or presumed low-grade meningiomas.

$\dagger$ "Combined" includes the full range of data from Tables 5 and 7. "Recent" refers to those reports published in the last 5 years (i.e., since 2002). 
aggressive intracranial meningiomas. Oncology 10:747-759, 1996

4. Al-Mefty O, Kersh JE, Routh A, Smith RR: The long-term side effects of radiation therapy for benign brain tumors in adults. $\mathbf{J}$ Neurosurg 73:502-512, 1990

5. Al-Mefty O, Topsakal C, Pravdenkova S, Sawyer JR, Harrison MJ: Radiation-induced meningiomas: clinical, pathological, cytokinetic, and cytogenetic characteristics. J Neurosurg 100: 1002-1013, 2004

6. Alvernia JE, Sindou MP: Preoperative neuroimaging findings as a predictor of the surgical plane of cleavage: prospective study of 100 consecutive cases of intracranial meningioma. J Neurosurg 100:422-430, 2004

7. Amirjamshidi A, Mehrazin M, Abbassioun K: Meningiomas of the central nervous system occurring below the age of 17: report of 24 cases not associated with neurofibromatosis and review of literature. Childs Nerv Syst 16:406-416, 2000

8. Andrews BT, Wilson CB: Suprasellar meningiomas: the effect of tumor location on postoperative visual outcome. J Neurosurg 69:523-528, 1988

9. Andrews DW, Faroozan R, Yang BP, Hudes RS, Werner-Wasik M, Kim SM, et al: Fractionated stereotactic radiotherapy for the treatment of optic nerve sheath meningiomas: preliminary observations of 33 optic nerves in 30 patients with historical comparison to observation with or without prior surgery. Neurosurgery 51:890-904, 2002

10. Annegers JF, Laws ER Jr, Kurland LT, Grabow JD: Head trauma and subsequent brain tumors. Neurosurgery 4:203-206, 1979

11. Barbaro NM, Gutin PH, Wilson CB, Sheline GE, Boldrey EB, Wara WM: Radiation therapy in the treatment of partially resected meningiomas. Neurosurgery 20:525-528, 1987

12. Baumert BG, Villa S, Studer G, Mirimanoff RO, Davis JB, Landau K, et al: Early improvements in vision after fractionated stereotactic radiotherapy for primary optic nerve sheath meningioma. Radiother Oncol 72:169-174, 2004

13. Berman D, Miller NR: New concepts in the management of optic nerve sheath meningiomas. Ann Acad Med Singapore 35: 168-174, 2006

14. Borovich B, Doron Y: Recurrence of intracranial meningiomas: The role played by regional multicentricity. J Neurosurg 64: 58-63, 1986

15. Carella RJ, Ransohoff J, Newall J: Role of radiation therapy in the management of meningioma. Neurosurgery 10:332-339, 1982

16. Central Brain Tumor Registry in the United States: Statistical Report: Primary Brain Tumors in the Unites States, 19921997. Hinsdale, Il: CBTRUS, 2001

17. Central Brain Tumor Registry of the United States: Statistical Report: Primary Brain Tumors in the United States, 19982002. Hinsdale, Il: CBTRUS, 2005

18. Chan RC, Thompson GB: Morbidity, mortality, and quality of life following surgery for intracranial meningiomas. A retrospective study of 257 cases. J Neurosurg 60:52-60, 1984

19. Chang SD, Adler JR Jr: Treatment of cranial base meningiomas with linear accelerator radiosurgery. Neurosurgery 41: 1019-1027, 1997

20. Chang SD, Adler JR Jr, Martin DP. LINAC radiosurgery for cavernous sinus meningiomas. Stereotact Funct Neurosurg 71: 43-50, 1998

21. Chuang CC, Chang CN, Tsang NM, Wei KC, Tseng CK, Chang JT, et al: Linear accelerator-based radiosurgery in the management of skull base meningiomas. J Neurooncol 66:241-249, 2004

22. Claus EB, Bondy ML, Schildkraut JM, Wiemels JL, Wrensch M, Black PM: Epidemiology of intracranial meningioma. Neurosurgery 57:1088-1095, 2005

23. Cleland J: Description of two tumors adherent to the deep surface of the dura mater. Glasgow Med J 11:148-159, 1864

24. Condra K, Buatti J, Mendenhall W, Friendman WA, Marcus RB
Jr, Rhoton AL: Benign meningiomas: primary treatment selection affects survival. Int J Radiat Oncol Biol Phys 39: 427-436, 1997

25. Cristante L: Surgical treatment of meningiomas of the orbit and optic canal: retrospective study with particular attention to the visual outcome. Acta Neurochir (Wien) 126:27-32, 1994

26. Cushing H: The meningiomas (dural endotheliomas). Their source and favoured seats of origin. Brain 45:282-316, 1922

27. Cushing H, Eisenhardt L: Meningiomas. Their Classification, Regional Behaviour, Life History, and Surgical End Results. Springfield, Ill: Charles C. Thomas, 1938, pp 56-73

28. Debus J, Wuendrich M, Pirzkall A, Hoess A, Schlegel W, Zuna I, et al: High efficacy of fractionated stereotactic radiotherapy of large base-of-skull meningiomas: long-term results. J Clin Oncol 19:3547-3553, 2001

29. DeMonte F, Al-Mefty O: Meningiomas, in Kaye A, Laws E (eds): Brain Tumors: An Encyclopedic Approach. Edinburgh: Churchill Livingstone, 1995, pp 675-704

30. DeMonte F, Marmor E, Al-Mefty O: Meningiomas, in Kaye A, Laws E (eds): Brain Tumors: An Encyclopedic Approach, ed 2. London: Churchill Livingstone, 2001, pp 719-750

31. DiBiase SJ, Kwok Y, Yovina S, Arena C, Naqvi S, Temple R, et al: Factors predicting local tumor control after gamma knife stereotactic radiosurgery for benign intracranial meningiomas. Int J Radiat Oncol Biol Phys 60:1515-1519, 2004

32. Dufour H, Muracciole X, Metellus P, Regis J, Chinot O, Grisoli F: Long-term tumor control and functional outcome in patients with cavernous sinus meningiomas treated by radiotherapy with or without previous surgery: Is there an alternative to aggressive tumor removal? Neurosurgery 48:285-296 2001,

33. Engenhart R, Kimmig BN, Hover KH, Wowra B, Sturm V, van Kaick G, et al: Stereotactic single high dose radiation therapy of benign intracranial meningiomas. Int J Radiat Oncol Biol Phys 19:1021-1026, 1990

34. Erdinçler P, Lena G, Sarioglu AC, Kuday C, Choux M: Intracranial meningiomas in children: review of 29 cases. Surg Neurol 49:136-141, 1998

35. Flickinger JC, Kondziolka D, Maitz AH, Lunsford LD: Gamma knife radiosurgery of imaging-diagnosed intracranial meningioma. Int J Radiat Oncol Biol Phys 56:801-806, 2003

36. Flint-Richter P, Sadetzki S: Genetic predisposition for the development of radiation-associated meningioma: an epidemiological study. Lancet Oncol 8:403-410, 2007

37. Ganz JC, Backlund EO, Thorsen FA: The results of Gamma Knife surgery for meningiomas, related to size of tumor and dose. Stereotact Funct Neurosurg 61 (Suppl 1):23-29, 1993

38. Ganz JC, Schröttner O, Pendl G: Radiation-induced edema after Gamma Knife treatment for meningiomas. Stereotact Funct Neurosurg 66 (Suppl 1):129-133, 1996

39. Ghim TT, Seo JJ, O’Brien M, Meacham J, Crocker I, Krawiecki $\mathrm{N}$ : Childhood intracranial meningiomas after high-dose irradiation. Cancer 71:4091-4095, 1993

40. Glaholm J, Bloom HJG, Crow JH: The role of radiotherapy in the management of intracranial meningiomas: the Royal Marsden Hospital experience with 186 patients. Int J Radiat Oncol Biol Phys 18:755-761, 1990

41. Goldsmith B: Meningioma, in Leibel S, Phillips T (eds): Textbook of Radiation Oncology. Philadelphia: WB Saunders, 1998, pp 324-340

42. Goldsmith BJ, Rosenthal SA, Wara WM, Larson DA: Optic neuropathy after irradiation of meningiomas. Radiology 185:71-76, 1992

43. Goldsmith BJ, Wara WM, Wilson CB, Larson DA: Postoperative irradiation for subtotally resected meningiomas. A retrospective analysis of 140 patients treated from 1967 to 1990. J Neurosurg 80:195-201, 1994

44. Goyal LK, Suh JH, Mohan DS, Prayson RA, Lee J, Barnett GH: Local control and overall survival in atypical meningioma: a retrospective review. Int J Radiat Oncol Biol Phys 46:57-61, 2000 
45. Hakim R, Alexander E III, Loeffler JS, Shrieve DC, Wen P, Fallon $\mathrm{MP}$, et al: Results of linear accelerator-based radiosurgery for intracranial meningiomas. Neurosurgery 42:446-454, 1998

46. Ho DMT, Hsu CY, Ting LT, Chiang H: Histopathology and MIB1 labeling index predicted recurrence of meningiomas: a proposal of diagnostic criteria for patients with atypical meningioma. Cancer 94:1538-1547, 2002

47. Hudgins WR, Barker JL, Schwartz DE, Nichols TD: Gamma Knife treatment of 100 consecutive meningiomas. Stereotact Funct Neurosurg 66 (Suppl 1):121-128, 1996

48. Hug EB, Devries A, Thornton AF, Muzenride JE, Pardo FS, Hedley-Whyte ET, et al: Management of atypical and malignant meningiomas: role of high-dose, 3D-conformal radiation therapy. J Neurooncol 48:151-160, 2000

49. Ildan F, Tuna M, Göçer AP, Boyar B, Bagdatoglu H, Sen O, et al: Correlation of the relationships of brain-tumor interfaces, magnetic resonance imaging, and angiographic findings to predict cleavage of meningiomas. J Neurosurg 91:384-390, 1999

50. Inamura T, Nishio S, Takeshita I, Fujiwara S, Fukui M: Peritumoral brain edema in meningiomas-influence of vascular supply on its development. Neurosurgery 31:179-185, 1992

51. Inskip PD, Mellemkjaer L, Gridley G, Olsen JH: Incidence of intracranial tumors following hospitalization for head injuries (Denmark). Cancer Causes Control 9:109-116, 1998

52. Ito M, Ishizawa A, Mikaoka M, Sato K, Ishii S: Intraorbital meningiomas. Surgical management and role of radiation therapy. Surg Neurol 29:448-453, 1988

53. Iwai Y, Yamanaka K, Ishiguro T: Gamma knife radiosurgery for the treatment of cavernous sinus meningiomas. Neurosurgery 52:517-524, 2003

54. Jääskeläinen J, Haltia M, Servo A: Atypical and anaplastic meningiomas: radiology, surgery, radiotherapy, and outcome. Surg Neurol 25:233-242, 1986

55. Jung HW, Yoo H, Paek SH, Choi KS: Long-term outcome and growth rate of subtotally resected petroclival meningiomas: experience with 38 cases. Neurosurgery 46:567-575, 2000

56. Kalkanis SN, Carroll RS, Zhang J, Zamani AA, Black PM: Correlation of vascular endothelial growth factor messenger RNA expression with peritumoral vasogenic cerebral edema in meningiomas. J Neurosurg 85:1095-1101, 1996

57. Kawahara Y, Niiro M, Yokoyama S, Kuratsu J: Dural congestion accompanying meningioma invasion into vessels: the dural tail sign. Neuroradiology 43:462-465, 2001

58. Kennerdell JS, Maroon JC, Malton M, Warren FA: The management of optic nerve sheath meningiomas. Am J Ophthal 106: 450-457, 1988

59. Kim DG, Kim ChH, Chung HT, Paek SH, Jeong SS, Han DH, et al: Gamma knife surgery of superficially located meningioma. J Neurosurg (Suppl) 102:255-258, 2005

60. King DL, Chang CH, Pool JL: Radiotherapy in the management of meningiomas. Acta Radiol Ther Phys Biol 3:26-33, 1966

61. Kinjo T, Al-Mefty O, Kanaan I: Grade zero removal of supratentorial convexity meningiomas. Neurosurgery 33:394-399, 1993

62. Kondziolka D, Flickinger J, Perez B: Judicious resection and/or radiosurgery for parasagittal meningiomas: outcomes from a multicenter review. Gamma Knife Study Group. Neurosurgery 43: 405-414, 1998

63. Kondziolka D, Lundsford LD, Flickinger JC: Stereotactic radiosurgery of meningiomas. Prog Neurol Surg 14:104-113, 1998

64. Kondziolka D, Niranjan A, Lindsford LD, Flickinger JC: Stereotactic radiosurgery for meningiomas. Neurosug Clin $\mathbf{N}$ Am 10:317-325, 1999

65. Korshunov A, Shishkina L, Golanov A: Immunohistochemical analysis of p16INK4a, p14ARF, p18INK4c, p21CIP1, p27KIP1 and p73 expression in 271 meningiomas correlation with tumor grade and clinical outcome. Int J Cancer 104:728-734, 2003

66. Kupersmith MJ, Warren FA, Newall J, Ransohoff J: Irradiation of meningiomas of the intracranial anterior visual pathway. Ann Neurol 21:131-137, 1987
67. Kuratsu J, Kochi M, Ushio Y: Incidence and clinical features of asymptomatic meningiomas. J Neurosurg 92:766-770, 2000

68. Kuratsu J, Ushio Y: Epidemiological study of primary intracranial tumors: a regional survey in Kumamoto prefecture in the southern part of Japan. J Neurosurg 84:946-950, 1996

69. Leber KA, Berglöff J, Pendl G: Dose-response tolerance of the visual pathways and cranial nerves of the cavernous sinus to stereotactic radiosurgery. J Neurosurg 88:43-50, 1998

70. Lee JY, Niranjan A, McInerney J, Kondziolka D, Flickinger JC, Lundsford LD: Stereotactic radiosurgery providing long-term tumor control of cavernous sinus meningiomas. J Neurosurg 97: 65-72, 2002

71. Liscák R, Simonová G, Vymazal J, Janousková L, Vladyka V: Gamma knife radiosurgery of meningiomas in the cavernous sinus region. Acta Neurochir (Wien) 141:473-480, 1999

72. Lui JK, Forman S, Hershewe GL, Moorthy CR, Benzil DL: Optic nerve sheath meningiomas: visual improvement after stereotactic radiotherapy. Neurosurgery 50:950-957, 2002

73. Liu JK, Forman S, Moorthy CR, Benzil DL: Update on treatment modalities for optic nerve sheath meningiomas. Neurosurg Focus 14:E7, 2003

74. Longstreth WT Jr, Dennis LK, McGuire VM, Drangsholt MT, Koepsell TD: Epidemiology of intracranial meningioma. Cancer 72:639-648, 1993

75. Louis DN, Ramesh V, Gusella JF: Neuropathology and molecular genetics of neurofibromatosis 2 and related tumors. Brain Pathol 5:163-172, 1995

76. Louis DN, Scheithauer BW, Budka H: Meningiomas, in Kleihues P, Cavenee WK (eds): World Health Organization Classification of Tumours. Pathology and Genetics of Tumours of the Nervous System. Lyon: IARC Press, 2000, pp 176-184

77. Maguire PD, Clough R, Friedman AH, Halperin EC: Fractionated external-beam radiation therapy for meningiomas of the cavernous sinus. Int J Radiat Oncol Biol Phys 44:75-79, 1999

78. Mahmood A, Qureshi NH, Malik GM: Intracranial meningiomas: analysis of recurrence after surgical treatment. Acta Neurochir (Wien) 126:53-58, 1994

79. McCarthy BJ, Davis FG, Freels S, Surawicz TS, Damek DM, Grutsch J, et al: Factors associated with survival in patients with meningioma. J Neurosurg 88:831-839, 1998

80. McDermott MW, Quiñones-Hinojosa A, Fuller GN, et al: Meningiomas, in Levin VA (ed): Cancer in the Nervous System, ed 2. New York: Oxford University, 2002, pp 269-299

81. Mendenhall WM, Amdur RJ, Morris CG, Friedman WA: Radiotherapy for optic nerve sheath meningiomas. J HK Coll Radiol 6:183-186, 2003

82. Milker-Zabel S, Zabel-du Bois A, Huber P, Schlegel W, Debus J: Intensity-modulated radiotherapy for complex shaped meningioma of the skull base: long-term experience of a single institution. Int J Radiat Oncol Biol Phys 68:858-863, 2007

83. Milosevic MF, Frost PJ, Laperriere NJ, Wong CS, Simpson WJ: Radiotherapy for atypical or malignant intracranial meningioma. Int J Radiat Oncol Biol Phys 34:817-822, 1996

84. Miralbell R, Linggood RM, de la Monte S, Convery K, Munzenrider JE, Mirimanoff RO: The role of radiotherapy in the treatment of subtotally resected benign meningiomas. J Neurooncol 13:157-164, 1992

85. Mirimanoff RO, Dosoretz DE, Linggood RM, Ojemann RG, Martuza RL: Meningioma: analysis of recurrence and progression following neurosurgical resection. J Neurosurg 62:18-24, 1985

86. Morita A, Coffey RJ, Foote RL, Schiff D, Gorman D: Risk of injury to cranial nerves after gamma knife radiosurgery for skull base meningiomas: experience in 88 patients. J Neurosurg 90: 42-49, 1999

87. Nägele T, Petersen D, Klose U, Grodd W, Opitz H, Voigt K: The "dural tail" adjacent to meningiomas studied by dynamic contrast-enhanced MRI: A comparison with histopathology. Neuroradiology 36:303-307, 1994

88. Nakamura JL, Pirzkall A, Carol MP, Xia P, Smith V, Wara WM, 
et al: Comparison of intensity-modulated radiosurgery with gamma knife radiosurgery for challenging skull base lesions. Int J Radiat Oncol Biol Phys 55:99-109, 2003

89. Nakamura M, Roser F, Michel J, Jacobs C, Samii M: The natural history of incidental meningiomas. Neurosurgery 53:62-71, 2003

90. Nakamura S, Hiyama H, Arai K, Nakaya K, Sato H, Hayashi M, et al: Gamma knife radiosurgery for meningiomas: four cases of radiation-induced edema. Stereotact Funct Neurosurg 66 (1 Suppl):142-145, 1996

91. Nakasu S, Hirano A, Shimura T, Llena JF: Incidental meningiomas in autopsy study. Surg Neurol 27:319-322, 1987

92. Narayan S, Cornblath WT, Sandler HM, Elner V, Hayman JA: Preliminary visual outcomes after three-dimensional conformal radiation therapy for optic nerve sheath meningioma. Int $\mathbf{J}$ Radiat Oncol Biol Phys 56:537-543, 2003

93. Nicolato A, Foroni R, Alessandrini F, Maluta S, Bricolo A, Gerosa M: The role of Gamma Knife radiosurgery in the management of cavernous sinus sinus meningiomas. Int J Radiat Oncol Biol Phys 53:992-1000, 2002

94. Nutting C, Brada M, Brazil L, Sibtain A, Saran F, Westbury C, et al: Radiotherapy in the treatment of benign meningioma of the skull base. J Neurosurg 90:823-827, 1999

95. Paek SH, Kim CY, Kim YY, Park IA, Kim MS, Kim DG, et al: Correlation of clinical and biological parameters with peritumoral edema in meningioma. J Neurooncol 60:235-245, 2002

96. Peele KA, Kennerdall JS, Maroon JC, Kalnicki S, Kazim M, Gardner T, et al: The role of postoperative irradiation in the management of sphenoid wing meningiomas. A preliminary report. Ophthalmology 103:1761-1767, 1996

97. Perry A: Meningiomas, in McLendon RE, Rosenblum MK, Bigner DD (eds): Russell \& Rubinstein's Pathology of Tumors of the Nervous System, ed 7. London: Hodder Arnold, 2006, p 427-474.

98. Perry A: Unmasking the secrets of meningiomas: a slow but rewarding journey. Surg Neurol 61:171- 173, 2004

99. Perry A, Dehner LP: Meningeal tumors of childhood and infancy. An update and literature review. Brain Pathol 13:386-408, 2003

100. Perry A, Giannini C, Raghavan R, Scheithauer BW, Banerjee R, Margraf L, et al: Aggressive phenotypic and genotypic features in pediatric and NF2-associated meningiomas: a clinicopathologic study of 53 cases. J Neuropathol Exp Neurol 60: 994-1003, 2001

101. Perry A, Gutmann DH, Reifenberger G: Molecular pathogenesis of meningiomas. J Neurooncol 70:183-202, 2004

102. Perry A, Louis DN, Scheithauer BW, Budka H, von Deimling A: Meningeal tumors, in Louis DN, Ohgaki H, Wiestler OD, Cavenee WK (eds): World Health Organization Classification of Tumours of the Central Nervous System. Lyon: IARC, 2007

103. Perry A, Scheithauer BW, Stafford SL, Lohse CM, Wollan PC: "Malignancy" in meningiomas: a clinicopathologic study of 116 patients, with grading implications. Cancer 85:20462056, 1999

104. Perry A, Stafford SL, Scheithauer BW, Suman VJ, Lohse CM: Meningioma grading: an analysis of histologic parameters. Am J Surg Pathol 21:1455-1465, 1997

105. Pieper DR, Al-Mefty O, Hanada Y, Buechner D: Hyperostosis associated with meningioma of the cranial base: secondary changes or tumor invasion. Neurosurgery 44:742-747, 1999

106. Pirzkall A, Debus J, Haering P, Rhein B, Grosser KH, Höss A, et al: Intensity modulated radiotherapy (IMRT) for recurrent, residual, or untreated skull-base meningiomas: preliminary clinical experience. Int J Radiat Oncol Biol Phys 55: 362-372, 2003

107. Pitz S, Becker G, Schiefer U, Wilhelm H, Jeremic B, Bamberg $\mathrm{M}$, et al: Stereotactic fractionated irradiation of optic nerve sheath meningioma: a new treatment alternative. Br J Ophthalmol 86:1265-1268, 2002

108. Pollock BE, Stafford SL, Link MJ: Gamma knife radiosurgery for skull base meningiomas. Neurosurg Clin N Am 11: 659-666, 2000

109. Pollock BE, Stafford SL, Utter A, Giannini C, Schreiner SA: Stereotactic radiosurgery provides equivalent tumor control to Simpson Grade 1 resection for patients with small-to mediumsize meningiomas. Int J Radiat Oncol Biol Phys 55: 1000-1005, 2003

110. Pourel N, Auque J, Bracard S, Hoffstetter S, Luporsi E, Vignaud JM, et al: Efficacy of external fractionated radiation therapy in the treatment of meningiomas: a 20-year experience. Radiother Oncol 61:65-70, 2001

111. Provias J, Claffey K, delAguila L, Lau N, Feldkamp M, Guha A: Meningiomas: role of vascular endothelial growth factor/vascular permeability factor in angiogenesis and peritumoral edema. Neurosurgery 40:1016-1026, 1997

112. Ragel B, Jensen RL: New approaches for the treatment of refractory meningiomas. Cancer Control 10:148-158, 2003

113. Ramsey AF, Blurton M, Ekstrand K: Edema following gamma knife radiosurgery for intracranial meningiomas. Int J Radiat Oncol Biol Phys 54 (1 Suppl):146-147, 2002 (Abstract)

114. Richards JC, Roden D, Harper CS: Management of sightthreatening optic nerve sheath meningioma with fractionated stereotactic radiotherapy. Clin Experiment Ophthalmol 33: 137-141, 2005

115. Riemenschneider MJ, Perry A, Reifenberger G: Histological classification and molecular genetics of meningiomas. Lancet Neurol 5:1045-1054, 2006

116. Roche PH, Pellet W, Fuentes S, Thomassin JM, Régis J: Gamma knife radiosurgical management of petroclival meningiomas results and indications. Acta Neurochir (Wien) 145: 883-888, 2003

117. Roche PH, Regis J, Dufour H, Fournier HD, Delsanti C, Pellet $\mathrm{W}$, et al: Gamma knife radiosurgery in the management of cavernous sinus meningiomas. J Neurosurg 93 (3 Suppl): 68-73, 2000

118. Ron E, Modan B, Boice JD Jr: Mortality after radiotherapy for ringworm of the scalp. Am J Epidemiol 127:713-725, 1988

119. Ron E, Modan B, Boice JD Jr, Alfandary E, Stovall M, Chetrit A, et al: Tumors of the brain and nervous system after radiotherapy in childhood. N Engl J Med 319:1033-1039, 1988

120. Saeed P, Rootman J, Nugent RA, White VA, Mackenzie IR, Koornneef L: Optic nerve sheath meningiomas. Ophthalmology 110:2019-2030, 2003

121. Schmidt MB: Ueber die Pacchionischen granulationen und ihr verhaeltniss zu den sarcomen und psammomen der dura mater. Virchows Arch 170:429-464, 1902

122. Selch MT, Ahn E, Laskari A, Lee SP, Agazaryan N, Solberg TD, et al: Sinus meningiomas. Int J Radiat Oncol Biol Phys 59:101-111, 2004

123. Shafron DH, Friedman WA, Buatti JM, Bova FJ, Mendenhall WM: Linac radiosurgery for benign meningiomas. Int J Radia Oncol Biol Phys 43:321-327, 1999

124. Shin M, Kurita H, Sasaki T, Kawamoto S, Tago M, Kawahara $\mathrm{N}$, et al: Analysis of treatment outcome after stereotactic radiosurgery for cavernous sinus meningiomas. J Neurosurg 95: 435-439, 2001

125. Shrieve DC, Hazard L, Boucher K, Jensen RL: Dose fractionation in stereotactic radiotherapy for parasellar meningiomas: radiobiological considerations of efficacy and optic nerve tolerance. J Neurosurg 101 (3 Suppl):390-395, 2004

126. Shrieve DC, Loeffler JS: Radiotherapy in the treatment of meningiomas, in Black PM, Loeffler JS (eds): Cancer of the Nervous System, ed 2. Philadelphia: Lippincott, Williams \& Wilkins, 2005, pp 357-366

127. Sibtain A, Plowman PN: Stereotactic radiosurgery. VII. Radiosurgery versus conventionally-fractionated radiotherapy 
in the treatment of cavernous sinus meningiomas. Br $\mathbf{J}$ Neurosurg 13:158-166, 1999

128. Simpson D: The recurrence of intracranial meningiomas after surgical treatment. J Neurol Neurosurg Psychiatry 20: 22-39, 1957

129. Smee R, Schneider M, Williams J: Optic nerve sheath meningiomas: the role of stereotactic radiotherapy, in Kondziolka D (ed): Radiosurgery. Basel: Karger, 2006, vol 6, pp 140-151

130. Smith JL, Vuksanovic MM, Yates BM, Bienfang DC: Radiation therapy for primary optic nerve meningiomas. J Clin Neuroophthalmol 1:85-99, 1981

131. Soyuer S, Chang EL, Selek U, Shi W, Maor MH, DeMonte F: Radiotherapy after surgery for benign cerebral meningioma. Radiother Oncol 71:85-90, 2004

132. Spiegelmann R, Nissim O, Menhel J, Alezra D, Pfeffer MR: Linear accelerator radiosurgery for meningiomas in and around the cavernous sinus. Neurosurgery 51:1373-1380, 2002

133. Stafford SL, Perry A, Suman VJ, Meyer FB, Scheithauer BW, Lohse CM, et al: Primarily resected meningiomas: Outcome and prognostic factors in 581 Mayo Clinic patients, 1978 through 1988. Mayo Clin Proc 73:936-942, 1998

134. Stafford SL, Pollock BE, Foote RL, Link MJ, Gorman DA, Schomberg PJ, et al: Meningioma radiosurgery: tumor control, outcomes, and complications among 190 consecutive patients. Neurosurgery 49:1029-1038, 2001

135. Stafford SL, Pollock BE, Foote RL, Link MJ, Schomberg PJ: Stereotactic radiosurgery for meningioma, in Pollock BE (ed): Contemporary Stereotactic Radiosurgery: Technique and Evaluation. Armonk, NY: Futura Publishing, 2002, pp 157-171

136. Stafford SL, Pollock BE, Leavitt JA, Foote RL, Brown PD, Link MJ, et al: A study of the radiation tolerance of the optic nerves and chiasm after stereotactic radiosurgery. Int J Radiat Oncol Biol Phys 55:1177-1181, 2003

137. Steinvorth S, Welzel G, Fuss M, Debus J, Wildermuth S, Wannenmacher $M$, et al: Neuropsychological outcome after fractionated stereotactic radiotherapy (FSRT) for base of skull meningiomas: a prospective 1-year follow-up. Radiother Oncol 69:177-182, 2003

138. Strang RD, Al-Mefty O: Comment on stereotactic radiosurgery for meningioma, in Pollock BE (ed): Contemporary Stereotactic Radiosurgery: Technique and Evaluation. Armonk, NY: Futura Publishing, 2002, pp 172-180

139. Strojan P, Popovic M, Jereb B: Secondary intracranial meningiomas after high-dose cranial irradiation: report of five cases and review of the literature. Int J Radiat Oncol Biol Phys 48: $65-73,2000$

140. Subach BR, Lunsford LD Kondziolka D, Maitz AH, Flickinger JC: Management of petroclival meningiomas by stereotactic radiosurgery. Neurosurgery 42:437-445, 1998

141. Taylor BW Jr, Marcus RB Jr, Friedman WA, Ballinger WE Jr, Million RR: The meningioma controversy: postoperative radiation therapy. Int J Radiat Oncol Biol Phys 15:299-304, 1988

142. Torres RC, DeSalles AAF, Frighetto L, et al: Long-term follow-up using Linac Radiosurgery and stereotactic radiotherapy as a minimally invasive treatment for intracranial meningiomas, in Kondziolka D (ed): Radiosurgery. Basel: Karger, 2004, pp 115-123

143. Turbin RE, Thompson CR, Kennerdell JS, Cockerham KP, Kupersmith MJ: A long-term visual outcome comparison in patients with optic nerve sheath meningioma managed with observation, surgery, radiotherapy, or surgery and radiotherapy. Ophthalmology 109:890-900, 2002

144. Urie MM, Fullerton B, Tatsuzaki H, Birnbaum S, Suit HD, Convery K, et al: A dose response analysis of injury to cranial nerves and/or nuclei following proton beam radiation therapy. Int J Radiat Oncol Biol Phys 23:27-39, 1992

145. Uy NW, Woo SY, Teh BS, Mai WY, Carpenter LS, Chiu JK, et al: Intensity-modulated radiation therapy (IMRT) for meningioma. Int J Radiat Oncol Biol Phys 53:1265-1270, 2002

146. Vendrely V, Maire JP, Darrouzet V, Bonichon N, San Galli F, Celerier D, et al: [Fractionated radiotherapy of intracranial meningiomas: 15 years' experience at the Bordeaux University Hospital Center.] Cancer Radiother 3:311-317, 1999 (Fr)

147. Vermeulen S, Young R, Li F, Meier R, Raisis J, Klein S, et al: A comparison of single fraction radiosurgery tumor control and toxicity in the treatment of basal and nonbasal meningiomas. Stereotact Funct Neurosurg 72 (1 Suppl):60-66, 1999

148. Waga S, Yamashita J, Handa H: [Recurrence of meningiomas.] Neurol Med Chir 17:203-208, 1977 (Japan)

149. Wahab M, Al-Azzawi F: Meningioma and hormonal influences. Climacteric 6:285-292, 2003

150. Wara WM, Bauman GS, Sneed PK, Larson DA, Karlsson UL: Brain, brainstem, and cerebellum, in Perez CA, Brady LW, Halperin EC, et al (eds): Principles and Practice of Radiation Oncology, ed 3. 1997, pp 818-820

151. Wara WM, Sheline GE, Newman H, Townsend JJ, Boldrey EB: Radiation therapy of meningiomas. AJR Ther Nucl Med 123:453-458, 1975

152. Wenkel E, Thornton AF, Finkelstein D, Adams J, Lyons S, De La Monte S, et al: Benign meningioma: partially resected, biopsied, and recurrent intracranial tumors treated with combined proton and photon radiotherapy. Int J Radiat Oncol Biol Phys 48:1363-1370, 2000

153. Willis J, Smith C, Ironside JW, Erridge S, Whittle IR, Everington D: The accuracy of meningioma grading: a 10-year retrospective audit. Neuropathol Appl Neurobiol 31: 141-149, 2005

154. Winkler C, Dornfeld S, Schwarz R, Friedrich S, Baumann M: [The results of radiotherapy in meningiomas with a high risk of recurrence. A retrospective analysis.] Strahlenthe Onkol 174:624-628, 1998

155. Yamashita J, Handa H, Iwaki K, Abe M: Recurrence of intracranial meningiomas, with special reference to radiotherapy. Surg Neurol 14:33-40, 1980

156. Zachenhofer I, Wolfsberger S, Aichholzer M, Bertalanffy A, Roessler K, Kitz K, et al: Gamma-Knife radiosurgery for cranial base meningiomas: experience of tumor control, clinical course, and morbidity in a follow-up of more than 8 years. Neurosurgery 58:28-36, 2006

157. Zwerdling T, Dothage J: Meningiomas in children and adolescents. J Pediatr Hematol Oncol 24:199-204, 2002

Manuscript submitted July 10, 2007.

Accepted August 23, 2007.

Address correspondence to: Leland Rogers, M.D., GammaWest Radiation Therapy, 1050 East South Temple, Salt Lake City, Utah 84102. email: leland@gammawest.com. 